\title{
ANALISA DAMPAK SEBELUM DAN SESUDAH SPIN-OFF PADA PROFITABILITAS: STUDI KASUS PADA UNIT USAHA SYARIAH DI INDONESIA
}

\author{
Dety Nurfadilah ${ }^{1)}$ \\ 1) Dosen Program Studi Manajemen FE UNKRIS \\ Alamat: Kampus UNKRIS, Jatiwaringin Jakarta Timur \\ Email : detynurfadila@gmail.com \\ , Sudarmawan Samidi ${ }^{2}$ \\ ${ }^{2)}$ Sekolah Tinggi Manajemen IPMI
}

\begin{abstract}
The purpose of this study is to analyze the impact before and after the spin-off of the Sharia Business Unit into a Sharia Commercial Bank on profitability. The data used in this study are ROA, ROE, and EPS which are divided into two periods, namely before the spin-off (2003-2009) and after the spin-off (2011-2017). Paired sample t-test and descriptive analysis of profitability performance are used to analyze data. The results of the study stated that there was a significant difference in ROE before and after the spin-off. However, there were no significant differences in ROA and EPS in the same two periods.
\end{abstract}

\section{Keywords: Sharia Business Unit, Sharia Commercial Bank, Spin Off, Profitability, ROE, EPS}

\section{PENDAHULUAN}

Bank Syariah merupakan lembaga keuangan yang memiliki karakteristik unik dimana seluruh kegiatan bisnisnya harus berdasarkan pada prinsip-prinsip Syariah, menyediakan layanan perbankan berbasis bagi hasil, tanpa riba, gharar, dan maysir; dan mencapai keseimbangan antara pengembalian ekonomi dan sosial. Konsep perbankan syariah, yang semula hanya merupakan diskusi teoretis, kini telah tumbuh dan berkembang. Bahkan, industri perbankan syariah saat ini telah berubah dari sekadar alternatif perbankan dengan sistem syariah menjadi industri perbankan syariah yang mampu memainkan perannya dalam perekonomian dunia.

Saat ini, keberadaan Bank Syariah menyebar hampir ke mayoritas negara Muslim, seperti Arab Saudi, Pakistan, Bangladesh, Malaysia, dan berkembang ke negara-negara di Kontinen Eropa, seperti United Kingdom, Ireland, Italy, Luxembourg, dan lainnya. Dalam konteks global, jumlah lembaga keuangan Syariah sudah mencapai 1,389 di tahun 2017 (Thomson Reuters, 2018) dengan pertumbuhan aset sebesar 6\% setiap tahunnya, dan di estimasi akan terus berkembang

Di Indonesia, pemerintah pernah berencana menerapkan sistem keuangan bagi hasil dalam berkredit pada tahun 1983, namun rencana tersebut baru dapat direalisasikan pada tahun 1991 dengan berdirinya PT. Bank Muamalat. Ketika krisis keuangan tahun 1998, Bank Muamalat menunjukkan kekuatannya untuk dapat bertahan dibandingkan dengan bank konvensional. Keadaan ini mendorong bank konvensional untuk membentuk Unit Usaha Syariah (UUS) sebagai strategi bisnisnya. Pada dasarnya sistem Unit Usaha Syariah (UUS ) sama dengan Bank Umum Syariah (BUS). Perbedaannya terletak pada status pendirian sistem syariahnya. Pada BUS statusnya independen dan tidak bernaung dibawah sistem perbankan konvensional. Sementara UUS statusnya tidak independent dan masih 
bernaung di bawah aturan manajemen perbankan konvensional, dimana bank konvensional masih menerapkan sistem riba (Indonesian Commercial Newsletter, 2009).

Untuk mendorong jumlah bank umum Syariah, Bank Indonesia (BI) melalui Peraturan Bank Indonesia No.11/10/PBI/2009 menyebutkan bahwa Unit Usaha Syariah (UUS) wajib dipisahkan (spin-off) dari bank umum konvensional (BUK) apabila nilai aset UUS telah mencapai 50\% dari total nilai aset BUK induknya, atau paling lambat 15 tahun sejak berlakunya Undang-Undang Nomor 21 Tahun 2008 tentang Perbankan Syariah atau pada tahun 2023. Sehingga, jika tidak memenuhi peraturan tersebut, maka akan ada pencabutan izin usaha UUS.

Meskipun kebijakan spin-off telah di sah kan oleh pemerintah, jumlah UUS di Indonesia masih belum mengalami penurunan yang drastis. Hal ini disebabkan oleh minimnya modal inti untuk membentuk Bank Umum Syariah (BUS) dimana bank konvensional harus memberikan modalnya untuk membangun BUS dan keraguan untuk memisahkan karena belum terlihat dampak yang jelas dari spin-off pada pertumbuhan aset dan profitabilitasnya (Al-Arif, 2014). Berdasarkan tabel 1, hanya ada penurunan sebesar 5 Unit Usaha Syariah dari tahun 2009 sampai 2018.

Tabel 1. Jumlah Unit Usaha Syariah di Indonesia

\begin{tabular}{|c|c|c|c|c|c|c|c|c|c|c|}
\hline Tahun & 2009 & 2010 & 2011 & 2012 & 2013 & 2014 & 2015 & 2016 & 2017 & 2018 \\
\hline Total & 26 & 23 & 24 & 24 & 23 & 22 & 22 & 21 & 21 & 21 \\
\hline \multicolumn{11}{|l|}{ Unit } \\
\hline \multicolumn{11}{|l|}{ Usaha } \\
\hline Syarial & & & & & & & & & & \\
\hline
\end{tabular}

Sumber: Otoritas Jasa Keuangan $(2011,2015,2018)$

Berdasarkan permasalahan tersebut, tujuan penelitian ini adalah untuk menganalisa dampak sebelum dan sesudah spin-off terhadap return on asset, return on equity, dan earning per share. Penelitian ini memberikan kontribusi pada ilmu perbankan Syariah melalui variabel dan periode data yang digunakan dimana penelitian sebelumnya fokus pada tingkat kesehatan bank yang lebih luas seperti CAR dan NPF dengan periode penelitian yang sangat minim (Kuncoro, 2018). Sedangkan peneliitan ini fokus kepada profitabilitas sebagai perhatian utama para praktisi dan periode yang lebih luas. Sehingga, hasil dari peneliitan ini dapat dijadikan sebagai acuan dan referensi oleh praktisi dan pembuat kebijakan dalam membuat keputusan strategis yang lebih efisien dan efektif.

Makalah ini disusun sebagai berikut: bagian II mengulas literatur, bagian III mengilustrasikan kerangka kerja metodologis, bagian IV memberikan hasil dari analisis statistik dan membahasnya berdasarkan studi-studi sebelumnya. Bagian V memberikan kesimpulan.

\section{LANDASAN TEORI}

\section{Konsep Dasar Spin-Off}

Menurut Umam dan Antoni (2015), Spin Off merupakan salah satu cara yang dilakukan oleh perusahaan untuk melakukan restrukturisasi agar perusahaan tetap dapat beroperasi secara efisien dan efektif. Kegiatan restrukturisasi juga dapat meningkatkan daya saing perusahaan, baik tingkat nasional maupun internasional. Kegiatan tersebut meliputi aspek bisnis, usaha, organisasi, manajemen, keuangan dan aspek hukum. Tubke et al., (2004) menjelaskan bahwa ada beberapa faktor yang mempengaruhi tindakan spin-off. 
Pertama, ukuran perusahaan dan perbedaan sektor bisnis antara perusahaan induk dengan anak perusahaan. Kedua, faktor yang berhubungan dengan organisasi dan manajemen perusahaan. Ketiga, faktor yang terakit dengan hubungan dan dukungan antara perusahaan induk dan anak perusahaan. Keempat, faktor yang terkait dengan transfer pengalaman dari perusahaan induk ke anak perusahaan. Kelima, faktor yang terkait dengan motivasi. Keenam, faktor yang terkait dengan lingkungan bisnis regional dan hokum kerangka kerja.

\section{Penelitian Terdahulu}

Penelitian mengenai dampak kebijakan spin-off terhadap Unit Usaha Syariah telah dilakukan oleh peneliti terdahulu. Kuncoro (2018) menganalisa kinerja keuangan pada saat sebelum dan sesudah melakukan kegiatan spin-off dengan menggunakan variabel finance to deposit ratio, biaya operasional pendapatan operasional (BOPO) dan return on asset pada Bank Jabar Banten periode 3 tahun sebelum (2011 - 2013) spin-off dan 3 tahun sesudah (2013 - 2016) spin-off. Hasil penelitian menunjukkan bahwa adanya perbedaan antara kinerja sebelum dan sesudah spin-off. Penelitian ini didukung oleh penelitian yang dilakukan oleh Fitriah dan Kurniasih (2016) yang menyatakan bahwa ada perbedaan yang signifikan pada capital adequacy ratio, non-performing financing, financing to deposit ratio, return on asset, return on equity, biaya operasional pendapatan operasional, dan nonperforming financing pada BNI Syariah dan BRI Syariah tahun $2011-2015$.

Namun, ada penelitian lain yang menunjukkan bahwa tidak ada perbedaan yang signifikan antara sebelum dan sesudah spin-off pada NPF, ROA, ROE, FDR di BNI Syariah (Chotib dan Utami, 2014). Hal ini sejalan dengan penelitian yang dilakukan oleh Hisyam dan Septiarini (2016) mengenai perbedaan antara CAR, BOPO, ROA, NPF, dan FDR sebelum dan sesudah spin-off pada periode 2013-2015.

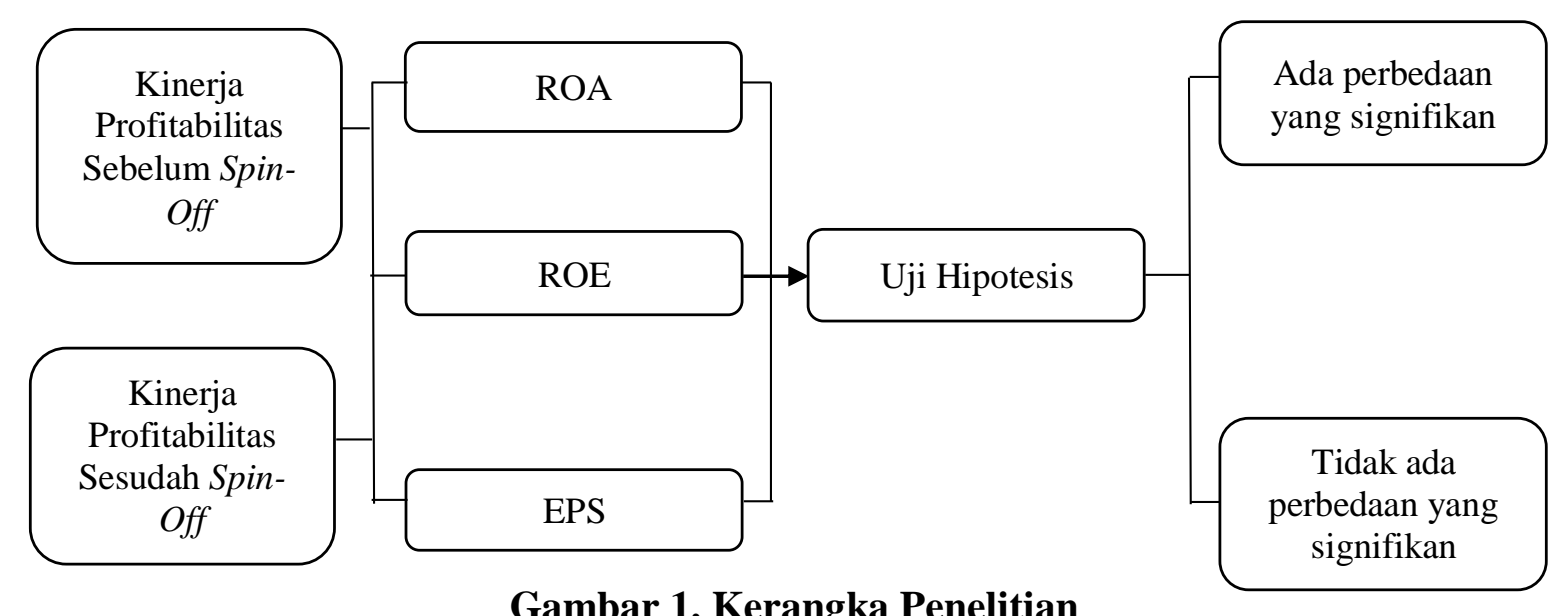

\section{Hipotesis Penelitian:}

H1: Ada perbedaan signifikan ROA antara sebelum dan sesudah spin-off

$\mathrm{H} 2$ : Ada perbedaan signifikan ROE antara sebelum dan sesudah spin-off

H3: Ada perbedaan signifikan EPS antara sebelum dan sesudah spin-off 


\section{METODE PENELITIAN}

\section{Sumber dan Data}

Sumber yang digunakan dalam penelitian ini adalah data sekunder yang diperoleh dari BNI Syariah dengan total aset terbesar ketiga di Indonesia dan telah melakukan spinoff pada tahun 2010. Untuk melakukan penelitian, data tahunan 2003 - 2017 dikumpulkan dari laporan keuangan Bank dan Publikasi Otoritas Jasa Keuangan.

\section{Metode Analisa}

Untuk mencapai tujuan penelitian, analisis rasio keuangan deskriptif digunakan untuk mengukur, mendeskripsikan, dan menganalisis kinerja profitabilitas selama periode 2008 - 2012 dan Paired sample t-test digunakan untuk menguji perbedaan signifikansi dalam periode sebelum spin-off (2003 - 2009) dan setelah spin-off (2011 - 2017). Paired sample t-test adalah teknik statistik yang digunakan untuk membandingkan keadaan sebelum dan sesudah dua periode penelitian. Metode ini telah banyak digunakan berkalikali dalam penelitian sebelumnya pada bidang ilmu sumber daya manusia, bisnis, perminyakan, dan lainnya (Raymond \& Chu, 2000; Taiwo, 2010; Daryanto \& Nurfadilah, 2017).

\section{Variabel}

\section{Return on Asset}

Menurut Brigham (2011), Aset yang dimaksud dalam ROA merupakan harta perusahaan, yang diperoleh dari modal sendiri maupun dari modal asing yang telah diubah perusahaan menjadi aktiva- aktiva perusahaan yang digunakan untuk kelangsungan hidup perusahaan.

$$
\text { Return on Asset }(\text { ROA })=\frac{\text { Net Income }}{\text { Total Asset }} \times 100 \%
$$

\section{Return on Equity}

Mengukur tingkat pengembalian bunga kepemilikan saham (ekuitas pemegang saham) dari pemilik saham biasa. Rasio ini mengukur efisiensi perusahaan dalam menghasilkan laba dari setiap unit ekuitas pemegang saham (Fraker, 2006).

$$
\text { Return on Equity }(\text { ROE })=\frac{\text { Net Income }}{\text { Shareholders'Equity }} 100 \%
$$

(2)

\section{Earnings per Share}

$$
\text { Earning per Share }=\frac{\text { Net Income }}{\text { Shareholders' }{ }^{\prime} \text { quity }} \quad 100 \%
$$


Menunjukkan perbandingan antara besarnya keuntungan bersih yang diperoleh investor atau pemegang saham terhadap jumlah lembar saham. Semakin tinggi nilai EPS keuntungan pemegang saham akan semakin besar.

\section{HASIL PENELITIAN}

\section{Kinerja Profitabilitas}

Gambar 2 memberikan informasi mengenai persentase ROA pada BNI Syariah sebelum (2003 - 2009) dan sesudah (2011-2017) spin-off. Secara keseluruhan, ada penurunan yang sangat drastis pada ROA sebelum spin-off dari 1,29\% menjadi $-3,6 \%$, sedangkan ROA setelah spin-off mengalami peningkatan yang stabil dari $0,77 \%$ menjadi $1,31 \%$.

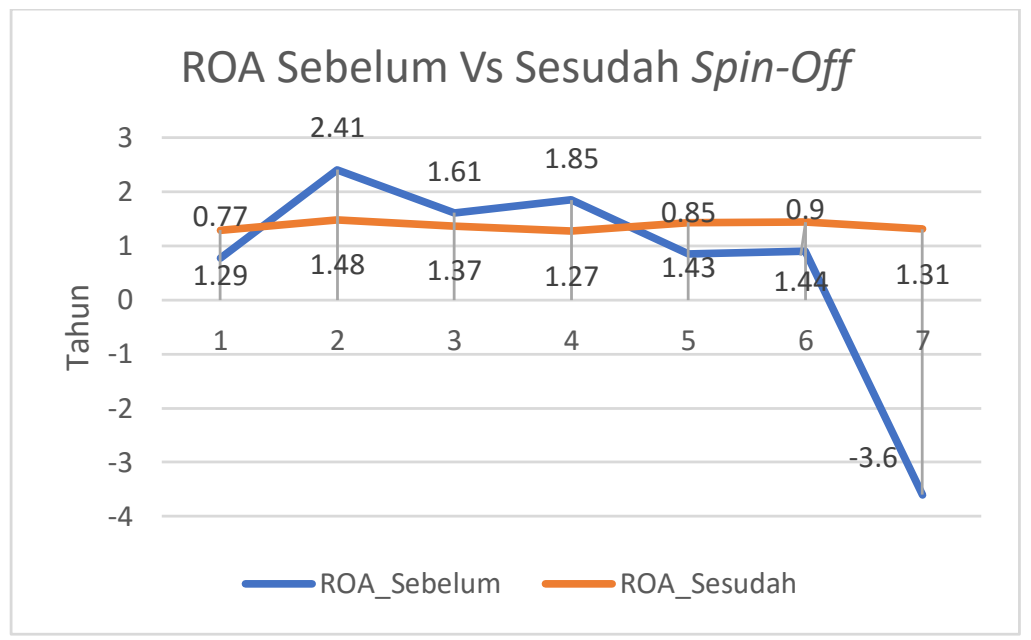

Gambar 2. ROA Sebelum Vs Sesudah Spin-Off

Gambar 3 memberikan informasi mengenai persentase ROE pada BNI Syariah sebelum (2003 - 2009) dan sesudah (2011-2017) spin-off. Secara keseluruhan, ada penurunan yang sangat signifikan pada ROE sebelum spin-off dari 3,5\% menjadi $-18,6 \%$, sedangkan ROE setelah spin-off mengalami peningkatan hampir dua kali lipat dari $6,63 \%$ menjadi $11,42 \%$.

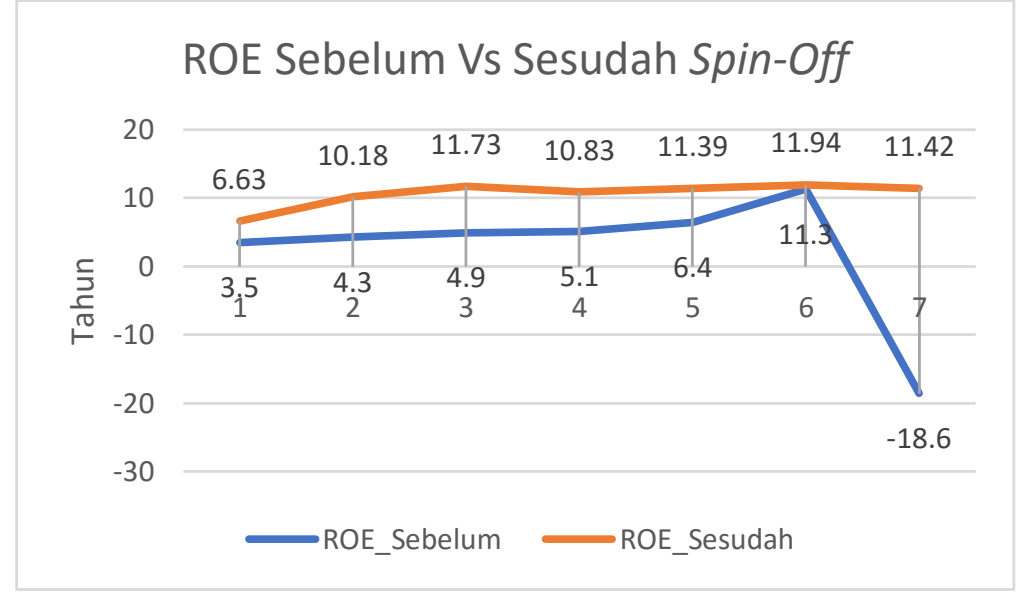

Gambar 3. ROE Sebelum Vs Sesudah Spin-Off 
Gambar 4 memberikan informasi mengenai persentase laba per saham (Earning per share/EPS) pada BNI Syariah sebelum (2003 - 2009) dan sesudah (2011-2017) spin-off. Secara keseluruhan, ada penurunan yang sangat signifikan pada EPS sebelum spin-off dari 60 menjadi 15.43, meskipun ada peningkatan yang tinggi pada tahun 2004 menjadi 231. Sedangkan EPS setelah spin-off mengalami peningkatan hampir empat kali lipat dari 56 menjadi 194.

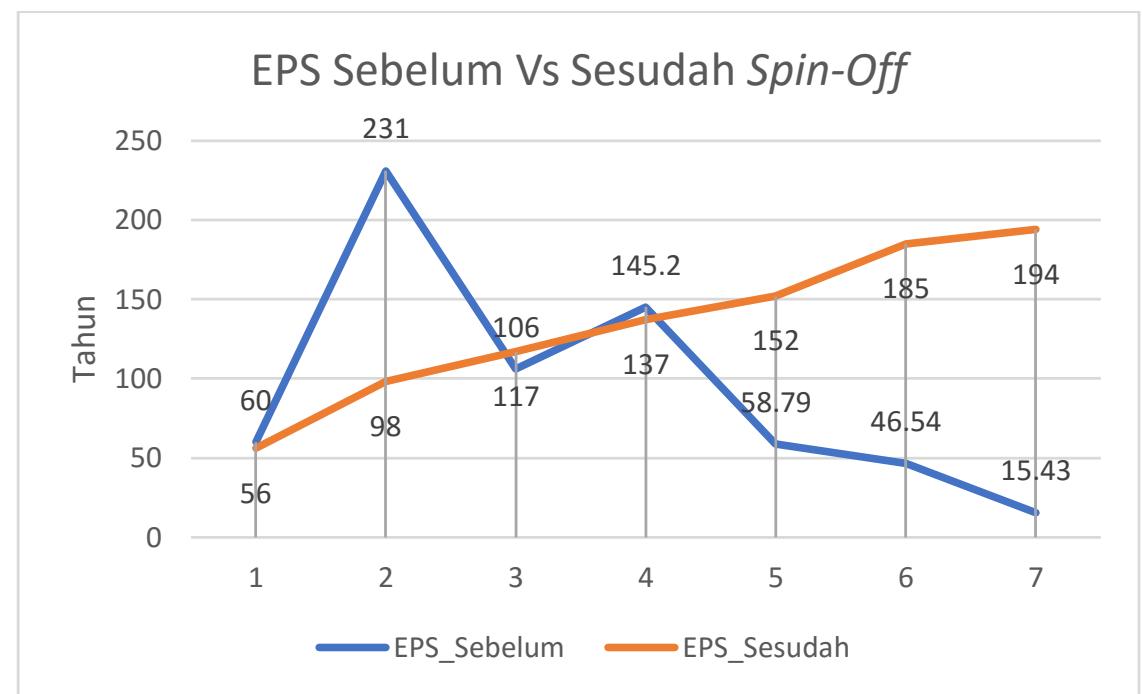

Gambar 4. EPS Sebelum Vs Sesudah Spin-Off

Uji Hipotesis

Tabel 2. Uji Paired Sample T-Test

\begin{tabular}{clcccc}
\hline Deskripsi & Periode & Means & $\begin{array}{c}\text { Std. } \\
\text { Deviation }\end{array}$ & $\begin{array}{c}\text { Paired } \\
\text { sample t-test }\end{array}$ & $\begin{array}{c}\text { Uji } \\
\text { Hipotesis }\end{array}$ \\
\hline \multirow{2}{*}{ ROA } & Sebelum & 0.6842 & 1.9845 & 0,194 & H1 ditolak \\
& Sesudah & 1.37 & 0.0822 & & \\
\multirow{2}{*}{ EPS } & Sebelum & 2.4142 & 9.6139 & 0,035 & H2 diterima \\
& Sesudah & 10.59 & 1.8420 & & \\
& Sebelum & 94.708 & 73.430 & 0,180 & H3 ditolak \\
& Sesudah & 134.14 & 48.653 & & \\
\hline
\end{tabular}

Tabel 2 memberikan informasi mengenai hasil dari paired sample t-test. Secara keseluruhan, satu hipotesis diterima dan dua hipotesis ditolak. Hasil penelitian menemukan bahwa return on equity (ROE) memiliki perbedaan signifikan secara statistik antara sebelum dan sesudah spin-off dengan nilai $\mathrm{p} \leq \alpha(0,035 \leq 0,05)$. Hasil ini menunjukkan bahwa kegiatan spin-off mempengaruhi perubahan ekuitas/modal. Namun, hasil peneliitan lainnya menemukan bahwa ROA dan EPS ditolak karena nilai $p>\alpha$ yaitu 0,194 $>0,05$ dan $0,180>0,05$ untuk masing-masing rasio. Hasil penelitian ini sejalan dengan penelitian sebelumnya yang dilakukan oleh Chotib dan Utami (2014) dan Hisyam dan Septiarini (2016). 


\section{KESIMPULAN DAN REKOMENDASI}

Berdasarkan hasil pengujian dan pembahasan dalam penelitian ini dapat disimpulkan bahwa ROE pada Bank Mandiri Syariah memiliki perbedaan signifikan atas peristiwa spinoff sedangkan ROA dan EPS tidak ditemukan perbedaan signifikan pada peristiwa spin off.

Rekomendasi yang dapat diberikan dari hasil penelitian ini adalah Unit Usaha Syariah harus lebih menyiapkan diri berpisah dari induk perusahaan baik dari segi modal, manajemen, SDM, dan juga kepemilikan saham. Selain itu hasil penelitian ini menunjukkan bahwa spin off pada variabel ROA meningkat. Sehingga spin-off merupakan strategi yang efektif, namun perlu membuat strategi yang lebih matang pada awal investasi.

Keterbatasan pada penelitian ini diharapkan dapat mendorong peneliti lainnya untuk menguji permasalahan ini dengan variabel yang lebih robust dan dapat memperpanjang periode data yang diambil sehingga dapat mencerminkan kinerja bank secara lebih luas.

\section{DAFTAR PUSTAKA}

Abugamea, G. (2018). Determinants of banking sector profitability: Empirical evidence from Palestine. Munich Personal RePEc Archive paper no. 89772.

Al Arif, M. N. R. (2014). Spin-off and its impact on the third party funds of Indonesian Islamic banking industry. Economic Journal of Emerging Markets, 6(1).

Anggraini, R. Yuliani, Umrie, R. H. (2017). Analisis tingkat kesehatan bank Syariah sebelum dan sesudah spin off. Ekspektra Jurnal Manajemen dan Bisnis, 1(1), 11-20.

Chotib, A., \& Utami, W. (2014). Studi Kinerja PT BNI Syariah Sesudah Pemisahan (Spin Off) dari PT Bank BNI (Persero) TBK. Akuntabilitas, 7(2), 94-108.

Fitriah, D. A., \& Kurniasih, A. (2016). Analisis perbandingan kinerja keuangan perbankan syariah (Studi: BNI Syariah dan BRI Syariah). NISBAH: JURNAL PERBANKAN SYARIAH, 2(2), 256-264

Fraker, G. (2006). Using economic value added (eve) to measure and improve bank performance. RMA-Arizona Chapter. Online available at: http://www.maaz.org/pictures/measuringbankperformance.pdf.

Hisyam, S. I. S., \& Septiarini, D. F. (2017). Analisis Perbandingan Kinerja Keuangan Bank Umum Syariah Hasil Spin Off Dan Non Spin Off Periode 2013-2015. Jurnal Ekonomi Syariah Teori dan Terapan, 3(11), 872.

Indonesian Commercial Newsletter. (2009). Laporan market intelligence perkembangan sistim bank Syariah di Indonesia. Retrieved on 9 August 2019 from http://www.datacon.co.id/BankSyariah2.html

Kuncoro, A., Yulianto, H. (2018). Kinerja keuangan sebelum dan sesudah spin off unit usaha Syariah ke bank umum Syariah. Jurnal Ekonomi Syariah, 6(2), 291 - 315.

Nasuha, A. (2012). Dampak kebijakan spin-off terhadap kinerja bank syariah. Al-Iqtishad: Jurnal Ilmu Ekonomi Syariah, 4(2).

Safitri, A. L. (2013). Pengaruh Earning Per Share, Price Earning Ratio, Return On Asset,

Debt To Equity Ratio dan Market Value Added terhadap Harga Saham dalam kelompok

Jakarta Islamic Index tahun 2008-2011 (Doctoral dissertation, Universitas Negeri

Semarang).

Thomson Reuters. (2018). Islamic finance development report 2018. Retrieved on 8 August 2019 from 
https://repository.salaamgateway.com/images/iep/galleries/documents/20181125124 744259232831.pdf

Tubke, A., Saavedra, P.A.T., and Gonzalez, J.G. (2004). Towards a first spin-off typology and a new concept for corporate spin-off research. International Journal of Technology Transfer and Commercialization, 3(3), 263-290. 